\title{
Editorial - Cultural Values in the Making: Governing through Intangible Heritage
}

\section{Guillaume Dutournier and Florence Padovani}

\section{(2) OpenEdition}

\section{Journals}

Electronic version

URL: https://journals.openedition.org/chinaperspectives/12179

DOI: 10.4000/chinaperspectives. 12179

ISSN: 1996-4617

\section{Publisher}

Centre d'étude français sur la Chine contemporaine

Printed version

Date of publication: 1 September 2021

Number of pages: $3-5$

ISBN: $979-10-91019-40-8$

ISSN: 2070-3449

\section{Electronic reference}

Guillaume Dutournier and Florence Padovani, "Editorial - Cultural Values in the Making: Governing through Intangible Heritage", China Perspectives [Online], 2021/3 | 2021, Online since 01 September 2021, connection on 18 November 2022. URL: http://journals.openedition.org/chinaperspectives/ 12179 ; DOI: https://doi.org/10.4000/chinaperspectives.12179 


\title{
Cultural Values in the Making: Governing through Intangible Heritage
}

\author{
GUILLAUME DUTOURNIER AND FLORENCE PADOVANI
}

th ntegral to the emergence of any modern state, the preservation of the traces of national past has become a major prerogative of today's governments, and China is no exception. A broad consensus now globally prevails on the a priori significance of "heritage" as a set of sites, constructions, and practices that deserve special treatment for their perpetuation and transmission. Taking shape mainly through the regulations of UNESCO, this "raison patrimoniale" (Poulot 2006: 16) is no longer just a matter for states; it concerns humanity as such, and one of its grounding ideas is the living and evolving nature of heritage, which "includes traditions or living expressions inherited from our ancestors and passed on to our descendants."1 At the same time, if the notion of heritage as a classifying term entails widely shared meanings, as an institutional device it is actualised in local contexts that are necessarily made of various references and complex realities. In the Chinese case, after a gradual emergence at the very end of the Qing empire and in the Republican era (1912-1949), followed by a period of selective denigrations and destructions during the Maoist era, the People's Republic of China has finally made its own the requirements to preserve and value heritage, making use of different labels and managing units at various levels for that purpose (Fresnais 2001, Zhang 2003). Although strongly rooted in the prerogatives of the socialist state under construction, this process has been largely inspired by foreign models, and has led not only to a successful integration into the world heritage lists, with 56 Chinese items now recognised as World Heritage Sites, ${ }^{2}$ but also to an active participation in heritage-related discussions and operations under the umbrella of UNESCO. Obviously, this massive commitment to heritage preservation does not simply reiterate a normative repertoire from international bodies: it also reflects endogenous trends, which are themselves part of a long-term trajectory regarding the sense and political use of the past (Gao 2000). Analyses of the making of Chinese heritage must keep this background in mind for a proper understanding of what is actually at work today in China's efficient mobilisation of this global discourse.

In the Chinese heritage trajectory, the ratification of the UNESCO Convention on "Intangible Cultural Heritage" (ICH) in 2004, followed by its official implementation in 2006, stands as a turning point, with the explicit will to rehabilitate practices that had once been deprecated as backward. This official impulse had been preceded in the 1980s by extensive scholarly compilations of "popular culture," which were still dominated by an objectifying approach of the unofficial sphere (notion of minjian 民間) entirely framed by the learned perspective. But the introduction of standards inspired and validated by UNESCO would significantly change the rules of the game. By putting forward a more inclusive approach, it has replaced the principle of exhaustiveness that still prevails in the aforementioned compilations with a criterion of representativeness, materialised by the establishment of selective lists corresponding to different administrative levels. This reorientation has been followed by an intense heritage fever throughout the country. A new set of evolving regulations has been deployed around the notion of "feiyi" (feiwuzhi wenhua yichan 非物質文化遺產) - the acronym for ICH in Chinese - on which an ever-increasing number of projects and initiatives is now relying to gain recognition for practices perceived as living tradition and to safeguard their lines of transmission.

This Chinese craze for $\mathrm{ICH}$ is striking in both its intensity and social extension. Placed in a long-term perspective, it appears as a step further in two directions. At the international level, Chinese investment in $\mathrm{ICH}$ projects can be seen as an attempt to become a leading contributor to this new type of cultural wealth (Bodolec 2014). By hosting important ICH UNESCO events, such as the Hangzhou International congress "Culture: Key to Sustainable Development" held in Zhejiang Province in May 2013 that resulted in the "Hangzhou Declaration - Placing Culture at the Heart of Sustainable Development Policies," or the more recent "Extended $44^{\text {th }}$ Session of the World Heritage Committee" held in Fuzhou in July 2021, China shows its will and capacity to maintain a high degree of organisational involvement. In addition, Beijing has become the seat of an agency called China International Training Centre for Intangible Cultural Heritage in the Asia-Pacific Region (CRIHAP), established according to UNESCO's terminology as a "Category 2 Centre" (CREAP), aimed at "contributing to the achievement of UNESCO's objectives by way of global, regional, subregional and interregional activities." ${ }^{\prime 3}$ The Chinese focus on training has its counterparts in Japan and Korea, where local CREAPs are respectively oriented along the lines of research and networking, making Asia the most dynamic part of the globe in Intangible Heritage protection with three centres out of seven all over the world. ${ }^{4}$

On the national level, it is not only the state that seems to have enthusiastically grasped the potentialities of feiyi, but also those in Chinese society who are able to appropriate new political watchwords. Going beyond the five domains delimited by the 2003 Convention (namely: oral traditions and expressions; performing arts; social practices, rituals and festive events;

1. https://ich.unesco.org/en/what-is-intangible-heritage-00003.

2. China has the largest number of sites labelled by UNESCO: 38 (cultural), 14 (natural), 4 (mixed) (http://whc.unesco.org/en/statesparties/CN).

3. https://ich.unesco.org/en/category2. All over the world there are only seven of these centres.

4. https://ich.unesco.org/en/category2\#china-international-training-centre-for-intangible-culturalheritage-in-the-asia-pacific-region-crihap. 
knowledge and practices concerning nature and the universe; traditional craftsmanship), ${ }^{5}$ China has enlarged to ten groups the practices admittible as feiyi, allowing more flexibility for local administrators to identify potential items (Duan 2018). Based on this taxonomy, myriad localities have set up their own museums or exhibition halls for displaying local ICH, be it already fully labelled or not, and seek to promote it at the district, provincial, or even national and international level. This remodelling of the Chinese heritage scene implies increasing competition among the groups involved, bringing together stakeholders with sometimes contradictory aspirations and interests (Madsen 2014; Shepherd and Yu 2013). Involvement in ICH entails different meanings for local governments eyeing the development of tourism; for individuals and collectives seeking recognition as inheritors of specific savoirfaire; for companies taking part in projects to improve their image; and for academics and local educated people asked to provide expertise. These groups all revolve around accreditation procedures opening admission to different lists: lists of items, lists of transmitters, lists at the national level for the few "ICH protection units" benefiting from state funding (Graezer Bideau and Yan 2018). ${ }^{6}$ These selection devices are likely to generate frustration among the applicants; but non-selected groups are not always excluded from valuation, for example when a traditional dance team not officially labelled as $\mathrm{ICH}$-bearer is still invited to participate in ICH-festivals (Zheng 2017). Such flexibility is made possible thanks to the prominent role played in the whole feiyi phenomenon by both academic and local scholars, be they recognised or not as representatives of the nowadays very productive "folklore studies" (minsuxue 民俗學). Ranging from researchers at major Beijing and provincial universities devoting research centres to $\mathrm{ICH}$, sometimes closely connected to international institutions, to local scholars doing fieldwork and writing local gazetteers (difangzhi 地方志) for local governments, these knowledge mediators negotiate ICH standards at the crossroads of different stakeholders and somehow balance the competitiveness among them by displaying a consensual ability for modelling names and classifying practices.

It is both in dialogue and in demarcation with this Chinese expertise on $\mathrm{ICH}$ that the present issue has been conceived. Our starting point is that the feiyi phenomenon is marked by a profound hybridity. While relying on rather recent global discourse that no doubt helped its rapid diffusion into Chinese society, it is also shaped by local consensus and specific justifications having to do with long-term conceptions of power and knowledge. From the simple fact of being embedded in the making of $\mathrm{ICH}$, Chinese scholars necessarily convey the conceptions in which they play an active role. Now, if we consider the historical emergence of the ICH category on a global scale, it corresponds to the arrival on the heritage scene of groups that were not part of it, and that pointed out the inadequacies of the existing legislation. This broadening of heritage legitimacy led to a redefinition of the relevant repertoire, and also to a new articulation between the scientific approach and cultural policies. In UNESCO agencies, this evolution has resulted in a progressive "anthropologisation of the notion of heritage" (Bortolotto 2011: 22), but also in a careful use of the terminology with a stress on "safeguarding" in the 2003 Convention, rather than on "protection" or "conservation" - a distinction that, admittedly, has been taken up by the PRC in its feiyi regulations (Freland 2009). All this normative trajectory reflects an increasing concern for agency among both communities and individuals, but also a growing reflexivity regarding the tensions at work in any heritage process, tensions that the UNESCO Convention on ICH tries to transcend through a great narrative namely, a conceptual synthesis as stable and inclusive as possible.

When considered carefully enough, in the long run and in all its dimensions, the Chinese heritagisation process appears at odds with this englobing narrative. The now widespread conceptual tools of "Heritage
Studies," especially when dealing with $\mathrm{ICH}$, are prone to highlight commonalities, such as a certain degree of compatibility with international norms, a shared awareness of the dangers of disappearance that threaten cultures, a correlated concern with their preservation, etc., and to be sure, our point is not to advocate the idea of a radical heterogeneity of the Chinese treatment of heritage. But at a time of state-promoted "cultural rejuvenation," it seems appropriate to pay attention to the ways through which "culture" is made visible through discourses and practices conveying a specific value to its alleged representatives. Two distinctive aspects in the Chinese ICH effervescence emerge from a comparison with other cases: the importance of classifications in balance with a lack of notional definition, and the crucial intermediary role played by local scholars in its implementation. In many cases, access to recognition under the heritage label supposes the managing of the former and the support of the latter. From this perspective, the new ICH discourse acclimated in China may be seen less as the result of a collective cultural claim than as one more element in the repertoire of knowledge allowing social recognition.

The articles brought together in this issue focus on the actors and processes of Chinese ICH in the making, in an attempt to highlight the principles of action and social dynamics that underpin this phenomenon. Whilst acknowledging its generic dimension, it mostly focuses on the Chinese feiyi experience from the specific values it enacts, and from the plurality of meanings it covers for the groups involved or impacted by it (Boltanski and Esquerre 2020; Heinich 2009). By studying diachronically through a set of dynamic cases the ways in which the Chinese have appropriated the concept of $\mathrm{ICH}$ and implemented it in a variety of concrete projects, we aim to question the driving forces behind the hybridisation of heritage discourse in the Chinese environment.

Christina Maags in her article addresses the question of commodification of cultural practices in Nanjing (Jiangsu Province). The author questions the contradictions between protection of heritage on one hand and economic pressure on the other hand, leading to a distortion in the value given to $\mathrm{ICH}$ commodities. She stresses a contradiction faced by actors in this field: "ICH safeguarding versus ICH promotion via the market." What set of market and non-market values, and what connections to the mutations of contemporary capitalism being more and more prone to exploit the past, underlie the implementation of a series of practices identified as "authentic" in China? Many ICH transmitters feel squeezed between the recognition of their art and the commodification of it. They often have to compete with "fake" products or luxury items in an unfair market. Maags cites the case of transmitters who exhibit their knowhow and sell their crafts in three different locations in Nanjing: the jiangsu Provincial Museum, the Ethnic Folklore Museum, and Fuzi Temple. In the first two, local authorities have organised an exhibition hall for $\mathrm{ICH}$ transmitters, setting up a provincial market for arts and crafts.

The second article, by Aurore Dumont, makes use of her intensive fieldwork in Inner Mongolia to show how each level of decision-making interprets the concept of ICH in its own way. She takes the case of "oboo cairns" worshipped by several ethnic groups to show the challenges brought by the new label and how each group tries to make the best of it to appropriate the monument. Each group, including local officials, is building a discourse and organising events in situ to claim a form of legitimacy over the oboo cairns. In this context, the new feiyi label becomes stakes of power.

5. https://ich.unesco.org/en/intangible-heritage-domains-00052.

6. http://english.www.gov.cn/policies/latestreleases/202106/10/content_WS60c18cb5c6d0df57 f98db093.html.

7. Xi Jinping has repeatedly devoted official discourses to this core topic of his ideological agenda. For example, in 2017: http://www.gov.cn/zhuanti/2017-10/27/content_5234876.htm. 
The third text, written by Su Junjie, a specialist of Yunnan ethnic minorities, raises the iconoclastic question of authenticity. This concept has been banned from official texts and most often from heritage studies, but in China it regularly springs up at the local level as the first argument to legitimate a choice between different items. Su Junjie analyses this contradiction in the facts and how decision-makers try to adjust and find a balance with and without authenticity. As Yunnan was one of the first provinces in China to get items labelled as $\mathrm{ICH}$, it allows for the drawing of a general analysis over an extended period of nearly twenty years.

The fourth text, by Lia Wei and Michael Long, critically analyses the process and biases through which calligraphy (shufa 書法) has been requalified as $\mathrm{ICH}$ since its inclusion in the UNESCO Representative List in 2009. This successful application, they argue, relies on a simplified conception of the calligraphic canon today deemed equivalent to "authentic" Chinese tradition. Yet, historically, it was rubbing practice that allowed for the formation and diffusion of calligraphic models - an activity from the scholar-artist's toolkit that surprisingly remains absent from current ICH listings. In order to question this apparent oversight in the current calligraphy heritagisation, the authors first retrace the role of rubbings in the historical development of calligraphic lineages: by borrowing from contemporary linguistic anthropological theory, they reconsider the traditional copying practices as a never-ending process of entextualisation by which forms and discourses were constantly removed from their original contexts into new, authoritative settings. In a second part, they show how this classical tradition is now being entextualised, through $\mathrm{ICH}$ discourse, by a new heritage regime promoting a simplified version of the history of calligraphy and, more generally, a fixed conception of cultural legitimacy.

The authors of these four articles each focus on one specific aspect of China's construction of living heritage. In an effort to follow the various actors of Chinese $\mathrm{ICH}$ over the long term and in their plural affiliations, they highlight the system of hybrid and shifting values expressed by their actions. From these case studies, a contrasting picture emerges regarding culturepower relations. While, in many cases, the appropriation and negotiation of the feiyi notion clearly correspond to critical moments in value ascription, allowing some actors to successfully reassess artefacts and practices as culturally meaningful, the role of knowledge-bearers in these reassessments - and more generally in the very definition of what "culture" should be seems to remain instrumental and most often unquestioned. By approaching the dynamics of Chinese ICH in its own terms, and simultaneously through a "view from afar," we hope to shed new light on this implicit dimension of the making of cultural values in contemporary China.

\section{Acknowledgements}

This special issue is the result of a workshop organised in Beijing in December 2020 by the Centre franco-chinois en sciences sociales (CFC) and the Beijing Centre of the École Française d'Extrême Orient (EFEO). We are grateful to the contributors, the anonymous reviewers, and the editors of China Perspectives who have made this special issue possible.

I Guillaume Dutournier is a researcher at the École Française d'Extrême Orient (EFEO), currently in charge of the EFEO Beijing Centre

(guillaume.dutournier@efeo.net).

I Florence Padovani is currently Director of the Centre franco-chinois en sciences sociales (CFC) in Beijing, and Associate Professor at Paris 1 University (florence.padovani@univ-paris1.fr).

\section{References}

BODOLEC, Caroline. 2014. "Les enjeux du patrimoine culturel immatériel pour la Chine." (Chinese Intangible Cultural Heritage at stakes), Tsanta 19: 19-30.

BOLTANSKI, Luc, and Arnaud ESQUERRE. 2020. Enrichment: A Critique of Commodities. Cambridge: Polity Press (first published in French, 2017).

BORTOLOTTO, Chiara (ed.). 2011. Le Patrimoine culturel immatériel. Enjeux d'une nouvelle catégorie. (Intangible Cultural Heritage: The Stakes of a New Category) Paris: Éditions de la Maison des sciences de l'homme.

DUAN, Xiaoqing 段曉卿. 2018. “非遺分類及非遺階元系統建構 研究" (Feiyi fenlei ji feiyi jieyuan xitong jiangou yanjiu, Research on the Classification of Intangible Heritage and the Construction of a Hierarchical System), Wenhua yichan (文化遺產) 4:9-16.

FRELAND, François-Xavier. 2009. Capturing the Intangible: Perspectives on the Living Heritage. Paris: UNESCO.

FRESNAIS, Jocelyne. 2001. La Protection du patrimoine en République populaire de Chine (Heritage Protection in the People's Republic of China), 1949-1999. Paris: CTHS.

GAO, Bingzhong 高丙中. 2000. “民間的儀式與國家的在場” (Minjian de yishi yu guojia de zaichang, Popular Rituals and the Presence of the State). In GUO Yuhua 郭於華 (ed.), 儀式與社會變遷 (Yishi yu shehui bianqian, Rituals and Social Change). Beijing: Shehui kexue wenxian chubanshe. 301-37.

GRAEZER BIDEAU, Florence, and Haiming YAN. 2018. "Historic Urban Landscape in Beijing - The Gulou Project and its Contested Memories." In Christina MAAGS, and Mariana SVENSSON, Chinese Heritage in the Making - Experiences, Negociations and Contestations. Amsterdam: Amsterdam University Press. 93-117.

HEINICH, Nathalie. 2009. La Fabrique du patrimoine. De la cathédrale à la petite cuillère (Heritage in the Making. From the Cathedral to the Spoon). Paris: Éditions de la Maison des sciences de l'homme.

MADSEN, Richard. 2014. "From Socialist Ideology to Cultural Heritage: the Changing Basis of Legitimacy in the People's Republic of China." Anthropology \& Medicine 21(1): 58-70.

POULOT, Dominique. 2006. "Introduction." Cultures \& Musées 8: 13-25.

SHEPHERD, Robert J., and Lawrence YU. 2013. Heritage Management, Tourism, and Governance in China. Managing the Past to Serve the Present. New York: Springer.

ZHANG, Liang. 2003. La naissance du concept de patrimoine en Chine. $X I X^{e}-X X^{e}$ siècles (The birth of Heritage Concept in China. XIXth-XXth centuries). Paris: Éditions recherches/lpraus.

ZHENG, Shanshan. 2017. "Religious Diversity and Patrimonialisation. A Case Study of the Nianli Festival in Leizhou Peninsula, China." Approaching Religion 7(1): 21-31. 